\title{
Variation in Disease Severity Caused by Phytophthora cinnamomi, P. plurivora, and Pythium cryptoirregulare on Two Rhododendron Cultivars
}

Jerry E. Weiland, ${ }^{\dagger}$ Carolyn F. Scagel, Niklaus J. Grünwald, E. Anne Davis, and Bryan R. Beck, U.S. Department of Agriculture, Agricultural Research Service, Horticultural Crops Research Laboratory, Corvallis, OR 97330; and Val J. Fieland, Department of Botany and Plant Pathology, Oregon State University, Corvallis, OR 97331

\begin{abstract}
Rhododendrons are an important crop in the ornamental nursery industry, but are prone to Phytophthora root rot. Phytophthora root rot is a continuing issue on rhododendrons despite decades of research. Several Phytophthora species are known to cause root rot, but most research has focused on P. cinnamomi, and comparative information on pathogenicity is limited for other commonly encountered oomycetes, including Phytophthora plurivora and Pythium cryptoirregulare. In this study, three isolates each of $P$. cinnamomi, P. plurivora, and Py. cryptoirregulare were used to inoculate rhododendron cultivars Cunningham's White and Yaku Princess at two different inoculum levels. All three species caused disease, especially at the higher inoculum level. $P$. cinnamomi and $P$. plurivora were the most aggressive pathogens, causing severe root rot, whereas Py. cryptoirregulare was a weak pathogen that only caused mild disease. Within each pathogen species,

isolate had no influence on disease. Both $P$. cinnamomi and $P$. plurivora caused more severe disease on Cunningham's White than on Yaku Princess, suggesting that the relative resistance and susceptibility among rhododendron cultivars might be similar for both pathogens. Reisolation of $P$. cinnamomi and $P$. plurivora was also greater from plants exhibiting aboveground symptoms of wilting and plant death and belowground symptoms of root rot than from those without symptoms. Results show that both P. cinnamomi and P. plurivora, but not Py. cryptoirregulare, are important pathogens causing severe root rot in rhododendron. This study establishes the risks for disease resulting from low and high levels of inoculum for each pathogen. Further research is needed to evaluate longer term risks associated with low inoculum levels on rhododendron health and to explore whether differences among pathogen species affect disease control.
\end{abstract}

Rhododendrons (Rhododendron species and cultivars) are an important ornamental nursery crop in the United States with an estimated nationwide production value of \$42.2 M (USDA National Agricultural Statistics Service 2015). Primarily grown for their ornamental flowers in the spring, many rhododendrons are also valued for leaf texture and color. Oregon and Washington State, in the Pacific Northwest (PNW), produce 37\% of the nation's supply of rhododendron, which is valued at $\$ 11.6 \mathrm{M}$.

Phytophthora root rot, caused by several Phytophthora species, has been a consistent problem in the rhododendron industry for many decades (White 1930). Despite the availability of fungicide treatments (Benson 1990) and genetic resistance (Hoitink and Schmitthenner 1975; Krebs and Wilson 2002), root rot remains one of the most serious diseases affecting rhododendron (Hoitink and Schmitthenner 1975; Hoitink et al. 2014; Krebs 2013). Losses of 10 to $100 \%$ have been reported, and the disease has been detected in nurseries worldwide (Benson et al. 1982; Englander et al. 1980; Hoitink and Schmitthenner 1969; Mrázková et al. 2011; Orlikowski and Szkuta 2008). Plants exhibiting aboveground symptoms of root rot (chlorosis, stunting, wilting, and death) are no longer salable and therefore represent a direct economic loss to growers.

From 2013 to 2017, Phytophthora and Pythium species were isolated from over 600 rhododendrons with root rot that were sampled from seven Oregon nurseries as part of a study to identify common

${ }^{\dagger}$ Corresponding author: J. E. Weiland; E-mail: jerry.weiland@ars.usda.gov

Funding: This work was funded, in part, by USDA ARS CRIS 2072-21000048-00D, 2072-12220-004-00-D, Floral and Nursery Research Initiative 2072-22000-039-15, Northwest Nursery Crop Research Center, and the Horticultural Research Institute.

*The $\boldsymbol{e}$-Xtra logo stands for "electronic extra" and indicates that two supplementary figures are published online.

Accepted for publication 30 May 2018.

This article is in the public domain and not copyrightable. It may be freely reprinted with customary crediting of the source. The American Phytopathological Society, 2018. soilborne pathogens of the PNW nursery industry (J. E. Weiland, unpublished data). Of the 450 isolates identified to date, Phytophthora cinnamomi Rands, Phytophthora plurivora T. Jung \& T.I. Burgess, and Pythium cryptoirregulare (Garzón, Yánez, and G.W. Moorman) were the most common pathogens isolated.

$P$. cinnamomi is considered the most virulent and widespread Phytophthora species causing root rot of rhododendron (Hoitink and Schmitthenner 1974; Hoitink et al. 2014), and most research has focused almost exclusively on this pathogen (Benson and Cochran 1980; Englander et al. 1980; Hoitink and Schmitthenner 1975; Krebs and Wilson 2002; Linderman and Zeitoun 1977; McGuire and Jackson 1973). Comparatively little is known about the ability of $P$. plurivora and Py. cryptoirregulare to cause root rot in rhododendron. P. plurivora is frequently isolated from rhododendron roots, stems, and leaves in pathogen surveys, but there have been no studies to evaluate its capacity as a root pathogen on this host (Knaus et al. 2015; Mrázková et al. 2011; Parke et al. 2014; Prospero et al. 2013; Rytkönen et al. 2012; Warfield et al. 2008). Py. cryptoirregulare is a widespread root pathogen on other plant hosts (Garzon et al. 2007), but has not previously been described from, or studied as a pathogen of, rhododendron. There are few studies that directly compare the ability of different soilborne oomycete species to cause root disease in rhododendron (Hoitink and Schmitthenner 1974). It is therefore unknown if resistance and susceptibility ratings based on inoculations with P. cinnamomi (Hoitink and Schmitthenner 1975; Krebs 2013, Krebs and Wilson 2002) will be similar in response to other root rotting oomycete species. In addition, the pathology of $P$. plurivora and $P y$. cryptoirregulare on rhododendrons has not been assessed using local isolates, so the risk of both pathogens to the PNW and national rhododendron industry is unknown.

While large amounts of Phytophthora inoculum can cause significant root rot, it is unknown whether smaller amounts of inoculum might also have production consequences. Previous research on Phytophthora root rot of rhododendron did not quantify inoculum on a per unit soil basis (e.g., as propagules or colony forming units per gram of soil), and only one study directly compared root rot severity resulting from different levels of soil inoculum (Krebs and Wilson 2002). This information is necessary to understand how inoculum density relates to disease incidence and severity, particularly among 
susceptible and resistant cultivars, and may help in the development of more effective disease control measures that are targeted toward the amount of inoculum present in the root environment.

Nurseries in the PNW produce almost a third of the nursery plants in the country and ship plants nationally and internationally (USDA National Agricultural Statistics Service 2015). Increasing global awareness about the risks of pathogen movement on infected nursery stock may become a significant trade barrier for the PNW nursery industry in the future. For example, Phytophthora species have been isolated from rhododendrons shipped to both New Jersey (White 1937) and Maryland (Bienapfl and Balci 2014) from West Coast nurseries, and it is suspected that $P$. cinnamomi was moved around the United States rhododendron industry on asymptomatic plants with root rot (Hoitink and Schmitthenner 1974). More recently, there is evidence that $P$. plurivora was introduced into the United States nursery industry from Europe (Schoebel et al. 2014). Understanding the risks of diseases that regionally impact crop value and may affect export trade is vital to the ongoing success of the horticultural industry in the PNW as well as to the industry on national and global scales.

Given the prevalence of $P$. cinnamomi, $P$. plurivora, and Py. cryptoirregulare isolated from rhododendrons with root rot in our survey, our overall goal was to compare the ability of these species to cause root rot in rhododendron. The specific objectives of this research were to: 1) compare the incidence and severity of root rot on rhododendrons inoculated at low (1 ppg) and high (100 ppg) inoculum levels with $P$. cinnamomi, $P$. plurivora, and Py. cryptoirregulare; 2) determine whether there are differences among isolates of each species to cause disease; and 3) evaluate whether two rhododendron cultivars are equally susceptible to each pathogen. To broaden the inference of our results, trials were conducted under different environmental conditions and with plant materials sourced from two nurseries. Pathogen species from this study that consistently cause greater disease incidence and severity will likely have more of a direct economic impact to the nursery industry than those that rarely cause severe disease. Information derived from this study will also be helpful in understanding the economic impact of pathogen populations detected by diagnostic procedures and can be used to develop effective control measures that balance cost with the potential for loss.

\section{Materials and Methods}

Isolate selection. Isolates of P. cinnamomi, P. plurivora, and $P y$. cryptoirregulare were selected based on their frequent isolation from rhododendron plants with root rot from seven PNW nurseries (J. E. Weiland, unpublished data). P. cinnamomi was also included as a positive control as a species known to cause severe root rot of rhododendron. This species was further used to confirm that our isolates were as virulent as those reported in the literature (primarily from the Southeast United States) and as a comparison to determine whether $P$. plurivora and Py. cryptoirregulare could cause similar amounts of disease (Benson and Cochran 1980; Hoitink and Schmitthenner 1975; Krebs and Wilson 2002; Linderman and Zeitoun 1977). To evaluate potential differences among isolates, one isolate of each species was selected from each of three Oregon nurseries (nine isolates total). Isolates R001 ( $P$. cinnamomi, GenBank Accession No. MG560190), R003 (P. plurivora, MG560192), and R002 (Py. cryptoirregulare, MG560196) were isolated from nursery A, a nursery producing containerized rhododendrons. Isolates R024 ( $P$. cinnamomi, MG560191), R039 (P. plurivora, MG560193), and R027 (Py. cryptoirregulare, MG560195) were obtained from the field production area of nursery $\mathrm{B}$, a nursery producing both containerized and field-grown rhododendrons. Isolates R056 (P. cinnamomi, MG560189), R064 (P. plurivora, MG560194), and R054 (Py. cryptoirregulare, MG560197) were isolated from the container production area of nursery $\mathrm{C}$, a nursery that propagates rhododendrons from cuttings and produces containerized and field-grown rhododendrons. All nurseries were located in the Willamette Valley, where the majority of nursery production occurs in Oregon, and located at least $50 \mathrm{~km}$ from the next nearest sampled nursery.

All isolates were obtained by plating necrotic, woody tissues from the roots or from lesions extending up from the root system into the plant collar. Tissues were first surface disinfested ( $1 \mathrm{~min}$ in $0.5 \%$ $\mathrm{NaOCl}, 30 \mathrm{~s}$ in $70 \% \mathrm{EtOH}$ ), then dried for 30 to $60 \mathrm{~s}$ in a laminar flow hood before plating onto PARP, a semiselective medium for Pythiaceious species (Kannwischer and Mitchell 1978). Isolates were identified using DNA sequence from the internal transcribed spacer (ITS) region and were 99 to $100 \%$ identical to sequences from type or extype isolates: P. cinnamomi (KC478663 and FJ801806), Py. cryptoirregulare (AY907893), and P. plurivora (FJ665225) (Garzon et al. 2007; Jung and Burgess 2009; Martin and Coffey 2012; Scanu et al. 2014).

Inoculum for all trials was produced by growing each pathogen in plastic fungal spawn bags (Fungi Perfecti, Olympia, WA) containing 3 liters coarse-grade vermiculite amended with 2.1 liters of dilute, clarified V8 juice amended with $\mathrm{CaCO}_{3}$ (Weiland et al. 2014). Each bag was autoclaved three times at 48-h intervals, then inoculated with a single isolate using a 1- to 2-week-old, colonized 20-ml petri plate of PARP cut into $1.5 \mathrm{~cm}^{2}$ pieces. A bag of V8-amended vermiculite was also prepared with an uncolonized plate of PARP agar to serve as noninfested inoculum for the noninoculated control treatments. Bags were heat sealed and incubated in the dark at $20^{\circ} \mathrm{C}$ for approximately 45 days with weekly mixing by hand for aeration and colonization. Inoculum was removed from the bags, air-dried for 3 days, and then stored in resealable polyethylene bags at $20^{\circ} \mathrm{C}$ until used for inoculation (within 1 week).

Inoculation methods and experimental design. Trial 1 consisted of 38 treatments in a randomized complete block design (RCBD) with 2 rhododendron cultivars $\times 3$ pathogen species $\times 3$ isolates per pathogen species $\times 2$ inoculum levels plus a noninoculated control for each cultivar. This initial trial provided the base for subsequent trials and modifications. For trials 2 and 3, additional noninoculated controls were added for a total of 48 treatments: 2 rhododendron cultivars $\times 4$ pathogens treatments $(P$. cinnamomi, $P$. plurivora, $P y$. cryptoirregulare, and none) $\times 3$ isolates per pathogen treatment $\times 2$ inoculum levels, with the "isolates" in all noninoculated control treatments receiving a different batch (isolate) of noninfested vermiculite inoculum. For each isolate or control treatment, infested or noninfested vermiculite inoculum was used to infest soilless media (Metro-Mix 840 PC, Sun Gro Horticulture, Agawam, MA) using a cement mixer for $10 \mathrm{~min}(14 \% \mathrm{vol} / \mathrm{vol}$ inoculum/media) at two different inoculum levels, 1 or 100 propagules per gram (ppg). The cement mixer was washed with water, then disinfested between treatments with a $0.3 \% \mathrm{NaOCl}$ wash for $10 \mathrm{~min}$. Infested and noninfested potting media were then distributed into 2.6-liter polystyrene pots (Dura-Pot 550S, Gage Industries, Lake Oswego, OR).

Two rhododendron cultivars were selected based on their reported susceptibility or resistance to root rot. Rhododendron 'Cunningham's White' (CW, RHS 58) was characterized as susceptible based on inoculation with P. cinnamomi (Hoitink and Schmitthenner 1975; Manning and Crossan 1966), while $R$. 'Yaku Princess' (YP, ARS 772) was considered more resistant than other cultivars based on the observations of wholesale rhododendron growers (J. E. Weiland, personal communication with growers) and on the presence of dense, abaxial leaf hairs, a characteristic associated with some resistance (Hoitink et al. 2014). Plants were obtained as rooted cuttings from two nurseries. For trials 1 and 2, both cultivars were obtained from nursery E, a nursery specializing in the propagation of nursery plants, as $10 \mathrm{~cm}$ rooted cutting liners grown in polystyrene liner trays $\left(310 \mathrm{~cm}^{3}\right.$ root volume cells). For trial 3, plants were obtained from nursery $\mathrm{C}$ as $7.5 \mathrm{~cm}$ (YP) or $15 \mathrm{~cm}$ (CW) rooted cuttings in flats of perlite, with much finer and smaller root systems than those of rooted cuttings from nursery E. Plant size at the beginning of trials 2 and 3 was estimated using biomass (oven dry weight, dw) and stem heights on 10 random plants.

For all trials, five replicate plants of each cultivar were transplanted into pots of infested or noninfested media as appropriate for each treatment. Plants were arranged according to a RCBD with 5 replicate blocks for a total of 190 plants (trial 1) or 240 plants (trials 2 and 3 ) and grown for 13 weeks after inoculation (WAI). Trials were conducted over 2 years when plants were at different stages of development and when there were differences in the greenhouse environment, irrigation methodology, and fertilizer applications. Trials started on 20 Jan 2015 (trial 1), 16 Mar 2016 (trial 2), and 8 June 2016 (trial 3). 
The soilless media in each pot was flooded two times during each trial at 7 and $9 \mathrm{WAI}$ to induce zoospore production and increase infection. For each flooding event, each pot was placed inside a 3.8-liter plastic bucket and filled with approximately 3.2 liters of tap water to about $1.5 \mathrm{~cm}$ below the surface of the media to achieve saturation. After $48 \mathrm{~h}$, pots were removed and plants were not watered again for 2 days. Caution was taken to avoid splash contamination between treatments, and all buckets were washed and disinfested with a $0.5 \%$ $\mathrm{NaOCl}$ solution for $24 \mathrm{~h}$ between flooding events.

Greenhouse conditions, fertilization, and watering. Greenhouse temperature controls were set for $22 / 16^{\circ} \mathrm{C}$ day/night temperatures, with supplemental lighting provided by $1,000 \mathrm{~W}$ high pressure multivapor lamps for $12 \mathrm{~h}$, which began 5 days after inoculation. In trial 1, air temperature was observed via thermometer readings, while in the trials 2 and 3, the air temperature and relative humidity (Supplementary Figs. S1 and S2) were measured using a HOBO U12 External Data Logger (Onset Computer Corp., Bourne, MA).

In trial 1, fertilization began $2 \mathrm{WAI}$ and occurred every 2 weeks thereafter using $150 \mathrm{ml}$ per pot of half-strength water soluble Miracle-Gro Azalea, Camellia, Rhododendron Plant Food (30-1010) (Miracle-Gro, Inc., Marysville, $\mathrm{OH}$ ), in lieu of water. All plants were watered three times per week, each receiving $150 \mathrm{ml}$ per pot. In trial 2, soilless media was initially amended with $1.8 \mathrm{~g} /$ liter slowrelease Harrell's 21-5-6 fertilizer (Harrell's, LLC, Lakeland, FL) while the media was mixing with the vermiculite inoculum in the cement mixer. Supplemental fertilization began 4 WAI and occurred monthly using $200 \mathrm{ml}$ per pot of the same rate of soluble fertilizer used in trial 1, in lieu of water. All plants were watered three times per week, each receiving $200 \mathrm{ml}$ per pot. In trial 3, the soilless media was amended with $3.6 \mathrm{~g} /$ liter of the same slow-release fertilizer used in trial 2. Subsequent fertilization and watering was the same as that in trial 2, except that soluble fertilizer applications were made when leaf greenness (estimated using a SPAD502 meter, Minolta Corp., Ramsey, NJ) was consistently $<28$ in the noninoculated control plants.

Disease and plant health evaluation. Plant shoots were visually evaluated weekly for the appearance of disease symptoms (wilting and shoot death) on a present (1) or absent (0) basis. In addition, for trials 2 and 3, plant health was evaluated by measuring leaf greenness and stomatal conductance (SC-1, Decagon Devices, Pullman, WA) (Scagel et al. 2011). Leaf greenness (SPAD value) was assessed on five replicate plants in each treatment. Three replicate measurements were taken on fully expanded, current-season leaves at three positions in the canopy and averaged for each plant. Leaf stomatal conductance $\left(g_{s}\right)$ was assessed on selected dates using fully expanded, current-season leaves at midday on five plants in each treatment.

At $13 \mathrm{WAI}$, the final number of wilting and dead plants in each treatment was recorded in preparation for harvest. Stems were cut from the root system, and the roots were washed free of media under running tap water. Root (four 1-cm-long roots collected at random from around the root ball) and stem samples (2-cm segment from the base of each stem) were collected from each plant and plated onto PARP to confirm infection by the appropriate pathogen or lack of infection in control plants. In trials 2 and 3, the root system was then photographed and rated for root rot according to one of three categories: healthy $=$ dense, white to tan root system with $<10 \%$ rot; moderate root rot $=$ patchy or partially rotted root system with 10 to $75 \%$ of the roots appearing dark brown; and, severe root rot $=$ sparse, mostly or completely rotted root system with $>75 \%$ of the roots appearing dark brown and having little structural integrity. The remaining shoots and roots from each plant were oven dried at $60^{\circ} \mathrm{C}$ to obtain shoot and root dry weights (biomass).

Data analyses. Frequency data (incidence of visual symptoms, pathogen isolation, and number of plants in each root rot category) were analyzed using $X^{2}$ with Yates' correction (Mantel 1974) and generalized linear models with a logit link function (Madden et al. 2002). Data are presented as the percentage of plants in each category. Data subjected to $X^{2}$ were analyzed to address the specific main effects and interactions. Differences in frequency among treatments were assessed at $P<0.05$.
Disease progression was evaluated by calculating the area under a disease progress curve based on plant death (AUDPCd) (Madden et al. 2007; Simko and Piepho 2012). Data for AUDPC did not meet ANOVA assumptions for normality and homogeneity of variance and were analyzed using Kruskal-Wallis (Sokal and Rohlf 2012) with differences assessed at $P<0.05$.

ANOVA assumptions for normality and homogeneity of variance of leaf greenness (SPAD), stomatal conductance $\left(g_{s}\right)$, biomass (dry weight; $d w$ ), and ratio of root $d w$ to shoot $d w(R: S$ ratio) data were assessed by examining P-P plots, using the Shapiro-Wilk test for normality (Shapiro et al. 1968) and using Brown-Forsythe test for homogeneity of variance (Brown and Forsythe 1974). SPAD and $g_{s}$ data required no transformation to meet ANOVA assumptions, but the $\mathrm{R}: \mathrm{S}$ ratio required log transformation to meet ANOVA assumptions. Transformed data were backtransformed for presentation.

SPAD, R:S ratio, and $g_{s}$ data were analyzed using mixed models with block and isolate as random effects. The R:S ratio data were analyzed using ANOVA with trial, cultivar, pathogen, and rate as main effects with isolate nested within pathogen. SPAD data were analyzed using repeated measures ANOVA with trial, cultivar, pathogen, and rate as main effects with isolate nested within pathogen. The $g_{s}$ data were analyzed separately for each trial using repeated measures ANOVA with cultivar, pathogen, and rate as main effects with isolate nested within pathogen. Control plants were compared with pathogen inoculated plants using Dunnett's Test at $P<0.05$. Differences among pathogens and rates, and isolates within each pathogen were compared using specific contrasts $(P<0.05)$.

There was large variation in biomass among trials and between cultivars. Therefore, ANOVA was used to analyze biomass data that had been normalized among trials and cultivars by expressing the biomass in the pathogen-inoculated treatments as a percentage relative to the noninoculated controls. For ANOVA, biomass data were normalized using controls within each block and analyzed using in mixed models with block and isolate as random effects and trial, cultivar, pathogen, and rate as main effects with isolate nested within pathogen. Differences among pathogens and rates, and isolates within each pathogen were compared using specific contrasts $(P<0.05)$.

\section{Results}

Noninoculated controls. Symptoms of wilting and shoot death were absent in control plants (Fig. 1). In trials 2 and 3, where SPAD and $g_{s}$ were measured, SPAD values were responsive to fertilization (Fig. 2). SPAD values were generally higher in trial 3 than in trial 2 $(P \leq 0.001)$, but within each trial, SPAD values were similar across both cultivars $(P \geq 0.525)$. Plants in trial 3 also initially had greater $g_{s}$ than in trial $2(P \leq 0.001)$, but within each trial, the $g_{s}$ of CW was similar to $(P \geq 0.199)$ or occasionally greater than $(P \leq 0.045)$ the $g_{s}$ of YP (Fig. 3).

The majority of control plants survived until the end of each trial (Fig. 4). Only three plants died during the entire experiment, and no Pythium or Phytophthora species were isolated from these, or any of the surviving plants (Table 1). At harvest, the root systems of most plants were dense and healthy, although some plants exhibited moderate root rot (Table 2). Final biomass differed depending on trial and cultivar (Table 3). Plants in trials 1 and 2, from nursery E, had the largest $\mathrm{R}: \mathrm{S}$ ratios and the most stems/plant, while the plants from nursery $\mathrm{C}$ in trial 3 had the lowest $\mathrm{R}: \mathrm{S}$ ratios and the fewest number of stems/plant. Across all three trials, plants of CW were similar in size (trial 1) or larger than YP (trials 2 and 3).

Pythium cryptoirregulare. Plants inoculated with Py. cryptoirregulare were very similar in appearance to controls, but there were indications that the pathogen decreased plant health. Symptoms of wilting and shoot death were almost completely absent in inoculated plants (Fig. 1). However, SPAD values from plants inoculated at 100 ppg (Fig. 2) and $g_{s}$ readings from plants inoculated at 1 and $100 \mathrm{ppg}$ (Fig. 3) were periodically lower than in controls depending on trial and cultivar. For example, in $\mathrm{CW}$, inoculation at $1 \mathrm{ppg}$ (data not shown) and $100 \mathrm{ppg}$ decreased SPAD values $(P \leq 0.001)$ in trial 3 starting 6 WAI (Fig. 2C). In YP, plants at 100 ppg (Fig. 2B and D), but not 1 ppg (data not shown), had lower SPAD values than 
controls from 8 to $9 \mathrm{WAI}$ in trial $2(P \leq 0.003)$ and 5 to $6 \mathrm{WAI}$ in trial $3(P \leq 0.009)$. Similarly, $g_{s}$ at both 1 and $100 \mathrm{ppg}$ was periodically lower than controls for CW and YP in both trials (Fig. 3), with differences appearing earlier in CW (4 WAI) than in YP (8 WAI) during trial 3 (data not shown) and lasting for a longer period of time for both cultivars in trial 3 than in trial 2 . There were no effects of isolate on either SPAD values or $g_{s}(P \geq 0.067)$.

By harvest, the majority of plants inoculated with Py. cryptoirregulare had survived (Fig. 4). Only three plants died during all three trials, which was the same number of controls that died in the control treatment. Approximately half of the inoculated plants had healthy root systems, while the remaining plants had moderate or severe root rot (Table 2). There were also fewer inoculated plants with healthy root systems compared with controls. Depending on trial, the pathogen had a variable impact on final biomass compared with controls
(Fig. 5). There were no effects of isolate on survival, root rot, or biomass $(P \geq 0.330)$.

Despite the low root rot ratings and the almost complete lack of aboveground symptoms of wilting and plant death, Py. cryptoirregulare was reisolated consistently from approximately one third of all inoculated plants during the entire experiment (Table 1). Reisolation was much more successful from the roots than from stems, but reisolation was similar across root rot categories, cultivars, and inoculum levels (Table 2, Fig. 6). There was no effect of isolate on reisolation $(P \geq 0.050)$, and neither $P$. cinnamomi nor $P$. plurivora was ever isolated from plants inoculated with $P y$. cryptoirregulare.

Phytophthora plurivora. In contrast to the noninoculated controls, symptoms of wilting and shoot death were common on rhododendrons inoculated with $P$. plurivora at $100 \mathrm{ppg}$ (Fig. 1), but there were also indications that inoculation at $1 \mathrm{ppg}$ decreased plant health. When

\section{Cunningham's White}

Yaku Princess

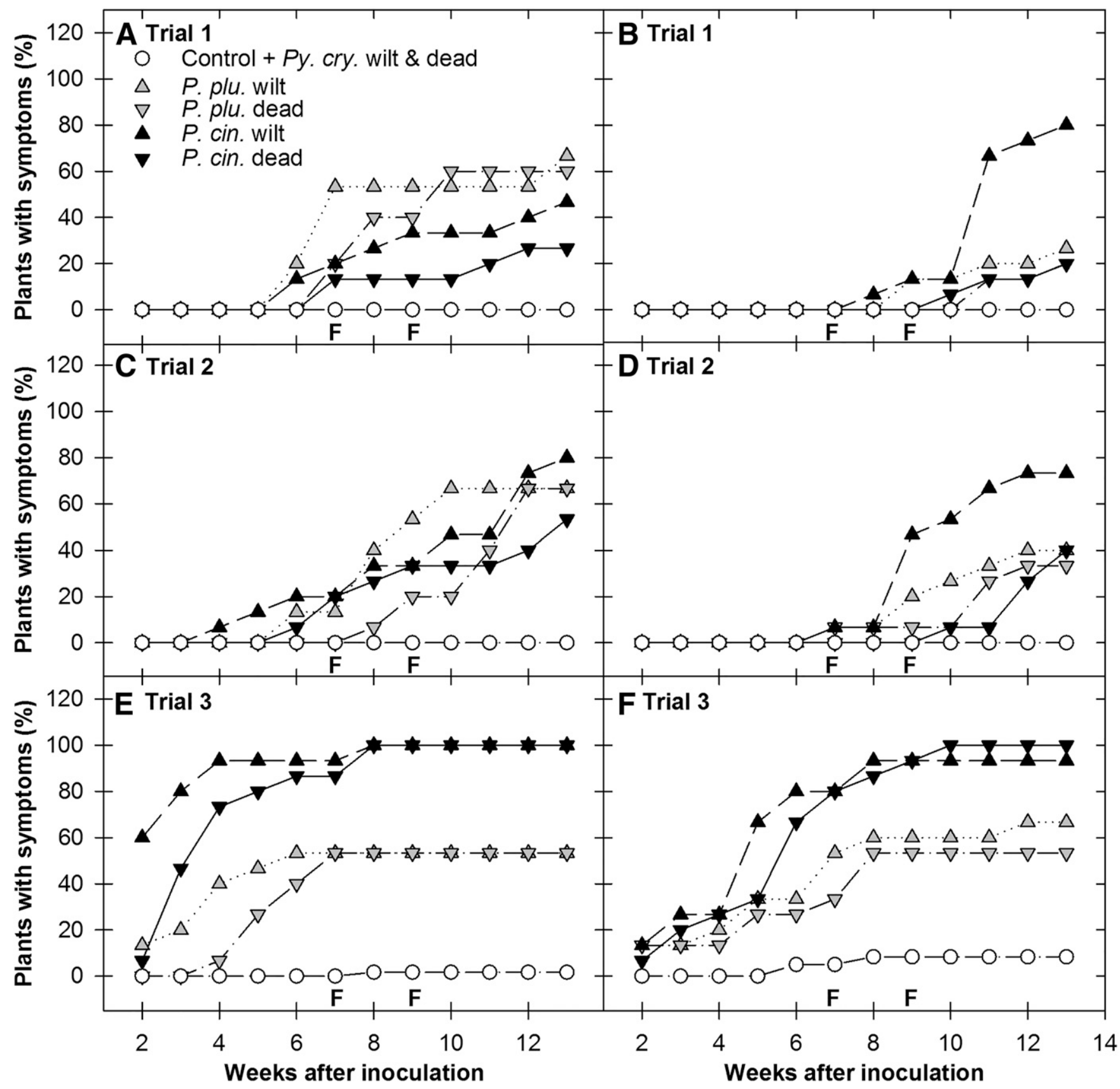

Fig. 1. Percentage of plants with aboveground symptoms of wilting or death in Rhododendron 'Cunningham's White' (A, C, and $\mathrm{E})$ and $R$. 'Yaku Princess' (B, D, and F) grown for 13 weeks after inoculation with noninfested media (Control) or media infested with one of three isolates each of Pythium cryptoirregulare (Py. cry.), Phytophthora plurivora (P. plu.), or Phytophthora cinnamomi (P. cin.) at $100 \mathrm{ppg}$ in three trials. Flooding $(\mathrm{F})$ for $48 \mathrm{~h}$ occurred at 7 and 9 weeks after inoculation. Cultivar and pathogen means across all isolates $(n=15)$. 
apparent, symptoms generally progressed from leaf chlorosis and/or a dull leaf appearance, to wilting, and finally plant death. However, these symptoms were rarely observed on plants inoculated at $1 \mathrm{ppg}$, where only two plants of CW developed wilt in trial 2. All other plants inoculated at 1 ppg appeared to have healthy shoots.

Wilting and plant death began much earlier and disease progressed more rapidly in plants inoculated with $P$. plurivora at $100 \mathrm{ppg}$ in trial 3 ( $2 \mathrm{WAI}$ ) than in either trial 1 or 2 (4 to $6 \mathrm{WAI})$, regardless of cultivar (Fig. 1). However, within each trial, disease generally started earlier (except trial 3) and progressed more rapidly in CW than in YP, with most disease in YP developing after the second flood event at $9 \mathrm{WAI}$ in trials 1 and 2 (Fig. 1B and D). Flooding had little impact on disease progress for either cultivar in trial 3 , where there was already substantial wilting and death before flooding was applied (Fig. $1 \mathrm{E}$ and $\mathrm{F}$ ). As a result of these differences in disease development among trials, AUDPCd was greater in CW than YP in trials 1 and $2(P \leq 0.001)$, but not in trial 3 , where AUDPCd was similar for the two cultivars $(P=0.315)$. There were no effects of isolate on disease development or AUDPCd $(P \geq 0.727)$.

SPAD values and $g_{s}$ generally supported observations of symptom development in the shoots and were frequently lower in plants inoculated with $P$. plurivora than in control plants. SPAD values in $\mathrm{CW}$ inoculated at either 1 (data not shown) or 100 ppg were lower than those of controls starting $6 \mathrm{WAI}$ in trial 3, but were rarely lower than controls in trial 2 (Fig. 2A and C). In YP, SPAD values of plants inoculated at $100 \mathrm{ppg}$ were below those of controls near the end of each trial (Fig. 2B and D), but values from YP inoculated at $1 \mathrm{ppg}$ (data not shown) were similar to or greater than plants inoculated at $100 \mathrm{ppg}$.
Plants inoculated at $1 \mathrm{ppg}$ periodically had lower $g_{s}$ than controls (Fig. 3). In comparison, plants inoculated at $100 \mathrm{ppg}$ frequently had lower $g_{s}$ than controls, and those values were often less than the $g_{s}$ observed at $1 \mathrm{ppg}$. There were no effects of isolate on either SPAD values or $g_{s}(P \geq 0.524)$.

By harvest, inoculation with $P$. plurivora at $100 \mathrm{ppg}$, but not $1 \mathrm{ppg}$, reduced survival for both cultivars by at least $40 \%$ compared with the controls (Fig. 4A and B). Survival was lower for CW than for YP at $100 \mathrm{ppg}$, except in trial 3, where survival was similar between the two cultivars (Fig. 4C). Almost $60 \%$ of the inoculated plants in trials 2 and 3 developed moderate or severe root rot, and there were a greater number of plants with severe root rot than in either the controls or in the Py. cryptoirregulare-inoculated plants (Table 2). Inoculation at 100 ppg reduced biomass by 35 to $50 \%$ in trials 2 and 3 (Fig. 5). There was a greater reduction in $\mathrm{CW}$ biomass than in YP, although this was significant only for trial $2(P=0.026)$. Inoculation at 1 ppg caused no reduction in biomass compared with controls. There were no effects of isolate on survival, root rot ratings, or biomass $(P \geq 0.173)$.

Across all three trials, $P$. plurivora was reisolated infrequently from plants inoculated at $1 \mathrm{ppg}$, but was reisolated from at least $37 \%$ of those inoculated at $100 \mathrm{ppg}$ (Fig. 6). In contrast to Py. cryptoirregulare, $P$. plurivora was commonly reisolated from the stems of plants at $100 \mathrm{ppg}$ (Fig. 6). Reisolation was more successful from $\mathrm{CW}$ than YP at $100 \mathrm{ppg}$, but was similar across cultivars at $1 \mathrm{ppg}$. Reisolation was also more successful from plants exhibiting aboveground symptoms of wilting and death (Table 1), and from those with severe root rot (Table 2), than from asymptomatic plants with healthy

\section{Cunningham's White}

\section{Yaku Princess}

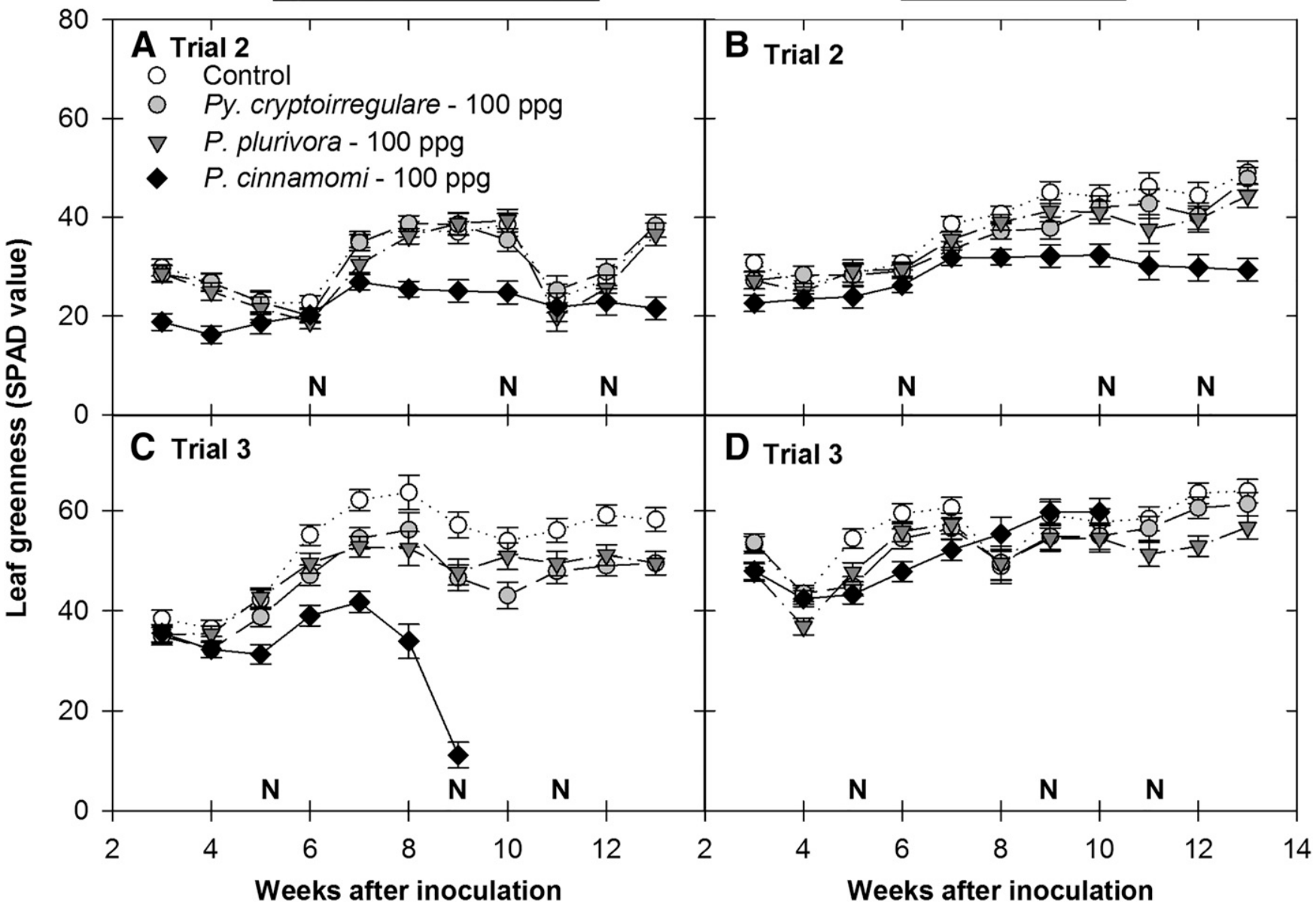

Fig. 2. Leaf greenness (SPAD value) in Rhododendron 'Cunningham's White' (A and $\mathbf{C}$ ) and $R$. 'Yaku Princess' (B and $\mathbf{D}$ ) grown in noninfested media (Control) or media infested with one of three isolates each of Pythium cryptoirregulare, Phytophthora plurivora, or Phytophthora cinnamomi at 100 ppg in two trials. Plants were grown for 13 weeks after inoculation into media containing slow release fertilizer and were amended with liquid fertilizer on weeks denoted by an $\mathrm{N}$. Data points are means across three isolates per pathogen (maximum $n=15$ for pathogen inoculated treatments) and error bars are least significant differences at $P=0.05$. Within each pathogen species, SPAD on plants inoculated at the $1 \mathrm{ppg}$ rate were similar or greater than those inoculated at the $100 \mathrm{ppg}$ rate. 
or moderate root rot ratings. There was no effect of isolate on reisolation $(P \geq 0.185)$, and neither Py. cryptoirregulare nor P. cinnamomi was reisolated from plants inoculated with $P$. plurivora.

Phytophthora cinnamomi. In contrast to the noninoculated controls, but similar to plants inoculated with $P$. plurivora, symptoms of wilting and shoot death were common on plants inoculated with P. cinnamomi at $100 \mathrm{ppg}$ (Fig. 1) and progressed in a similar manner from chlorosis to wilting, then plant death. Symptoms were rarely observed on plants inoculated at $1 \mathrm{ppg}$, except in trial 2 where they were common on both CW (11/15 plants) and YP (9/15 plants). Similar to $P$. plurivora, wilting and plant death in both cultivars began much earlier and disease progressed more rapidly in trial 3 (2 WAI) than in either trial 1 or 2 (4 to $6 \mathrm{WAI}$ ). However, within each trial, symptoms generally developed earlier (except trial 3) and disease progressed more rapidly in CW than in YP at 100 ppg (Fig. 1), with most disease in YP developing after the second flood event at 9 WAI in trials 1 and 2 (Fig. 1B and D). Flooding had little impact on disease progress in trial 3, where there was already substantial wilting and death before flooding was applied (Fig. 1E and F). AUDPCd was greater in $\mathrm{CW}$ than YP, but these differences were only significant for trials 2 and $3(P \leq 0.001)$. There were no effects of isolate on disease development or AUDPCd $(P=0.922)$.

SPAD values and $g_{s}$ generally supported observations of symptom development in the shoots and were frequently lower in plants inoculated with $P$. cinnamomi than in controls or in plants inoculated with Py. cryptoirregulare or P. plurivora. For both cultivars, SPAD values for $P$. cinnamomi were lower than all other treatments at multiple measurement dates (Fig. 2). SPAD values also were either not responsive, or less responsive, to fertilization compared with all of the other treatments. Plants inoculated with $P$. cinnamomi always had lower $g_{s}$ than plants from any other treatment in trial 2 (Fig. 3A and B). In trial 3 , however, only plants inoculated with $P$. cinnamomi at
$100 \mathrm{ppg}$ had lower $g_{s}$ than the other treatments (Fig. 3C and D). There were no effects of isolate on either SPAD values or $g_{s}(P \geq 0.378)$.

By the end of the experiment, $P$. cinnamomi had killed more plants (37\% of 180 inoculated plants) than $P$. plurivora $(24 \%)(P=0.016)$. Inoculation at $100 \mathrm{ppg}$ reduced survival by at least $23 \%$ compared with controls (Fig. 4A and B). Inoculation at $1 \mathrm{ppg}$ did not reduce survival, except in trial 2, where survival was reduced by $53 \%$ in $\mathrm{CW}$ and $27 \%$ in YP. Unlike P. plurivora, survival was similar for both CW and YP (Fig. 4C). Most plants in trials 2 and 3 developed severe root rot, and there were a greater number of plants with severe root rot than in all other treatments (Table 2). Inoculation with $P$. cinnamomi also reduced biomass by up to $94 \%$ and caused a greater reduction than observed in all other treatments (Fig. 5). P. cinnamomi caused a greater reduction in CW biomass than in YP for trials 2 and 3, but not trial 1. There were no effects of isolate on survival, root rot ratings, or biomass $(P \geq 0.138)$.

Across all three trials, $P$. cinnamomi was reisolated from $33 \%$ of all plants inoculated at $1 \mathrm{ppg}$ and from $99 \%$ of all plants inoculated at $100 \mathrm{ppg}$. However, the bulk of reisolation at $1 \mathrm{ppg}$ came from plants in trial 2 (25/30 plants). Similar to $P$. plurivora, $P$. cinnamomi was commonly reisolated from the stems of plants. However, the pathogen was reisolated more frequently than $P$. plurivora from the roots, and there were no differences in reisolation frequency based on cultivar (Fig. 6). Reisolation was also more successful from plants exhibiting aboveground symptoms of wilting and death (Table 1), and from plants with severe root rot (Table 2), than from asymptomatic plants with healthy or moderate root rot ratings. There was no effect of isolate on reisolation $(P=0.286)$, and neither Py. cryptoirregulare nor $P$. plurivora was reisolated from plants inoculated with $P$. cinnamomi.

\section{Discussion}

The cultivars assessed in this study differed in susceptibility to $P$. cinnamomi and $P$. plurivora. Disease progress was faster and final

\section{Cunningham's White}

\section{Yaku Princess}

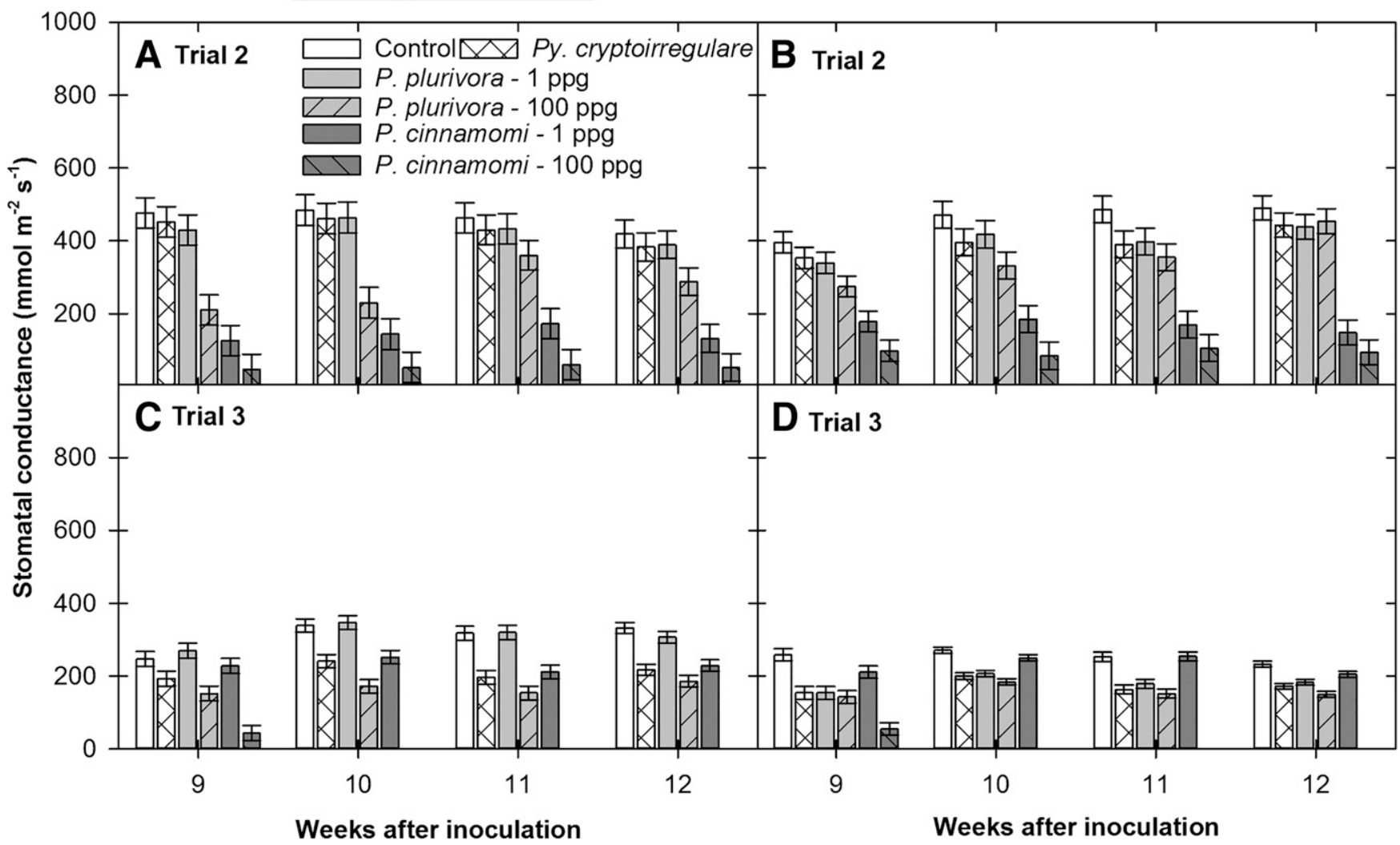

Fig. 3. Midday leaf stomatal conductance $\left(g_{s}\right)$ in Rhododendron 'Cunningham's White' ( $\mathbf{A}$ and $\left.\mathbf{C}\right)$ and $R$. 'Yaku Princess' (B and $\left.\mathbf{D}\right)$ grown for 13 weeks after inoculation with Pythium cryptoirregulare, Phytophthora plurivora, or Phytophthora cinnamomi. Plants grown for 13 weeks after inoculation in noninfested media (control) or media infested with one of three isolates of each pathogen at 1 or $100 \mathrm{ppg}$ in two trials. Columns are means across all inoculum levels and isolates for controls and Py. cryptoirregulare $(n=30)$ or across isolates at each inoculum level for $P$. plurivora and $P$. cinnamomi $(n=15)$. Error bars are least significant differences at $P<0.05$. For $P$. cinnamomi, no mean is given when $n<3$. 
biomass was lower in inoculated CW compared with YP for both pathogens despite the fact that YP generally started out smaller than $\mathrm{CW}$ at the beginning of each trial and that plants were sourced from different nurseries at different times. These results confirm previous research establishing that $\mathrm{CW}$ is susceptible to $P$. cinnamomi
(Hoitink and Schmitthenner 1975) and show that this cultivar is also similarly susceptible to $P$. plurivora. The susceptibility of YP is not described in the literature, but both of its parents, $R$. degronianum subsp. yakushimanum and $R$. King Tut, were susceptible to $P$. cinnamomi (Hoitink and Schmitthenner 1975). Nevertheless, growers
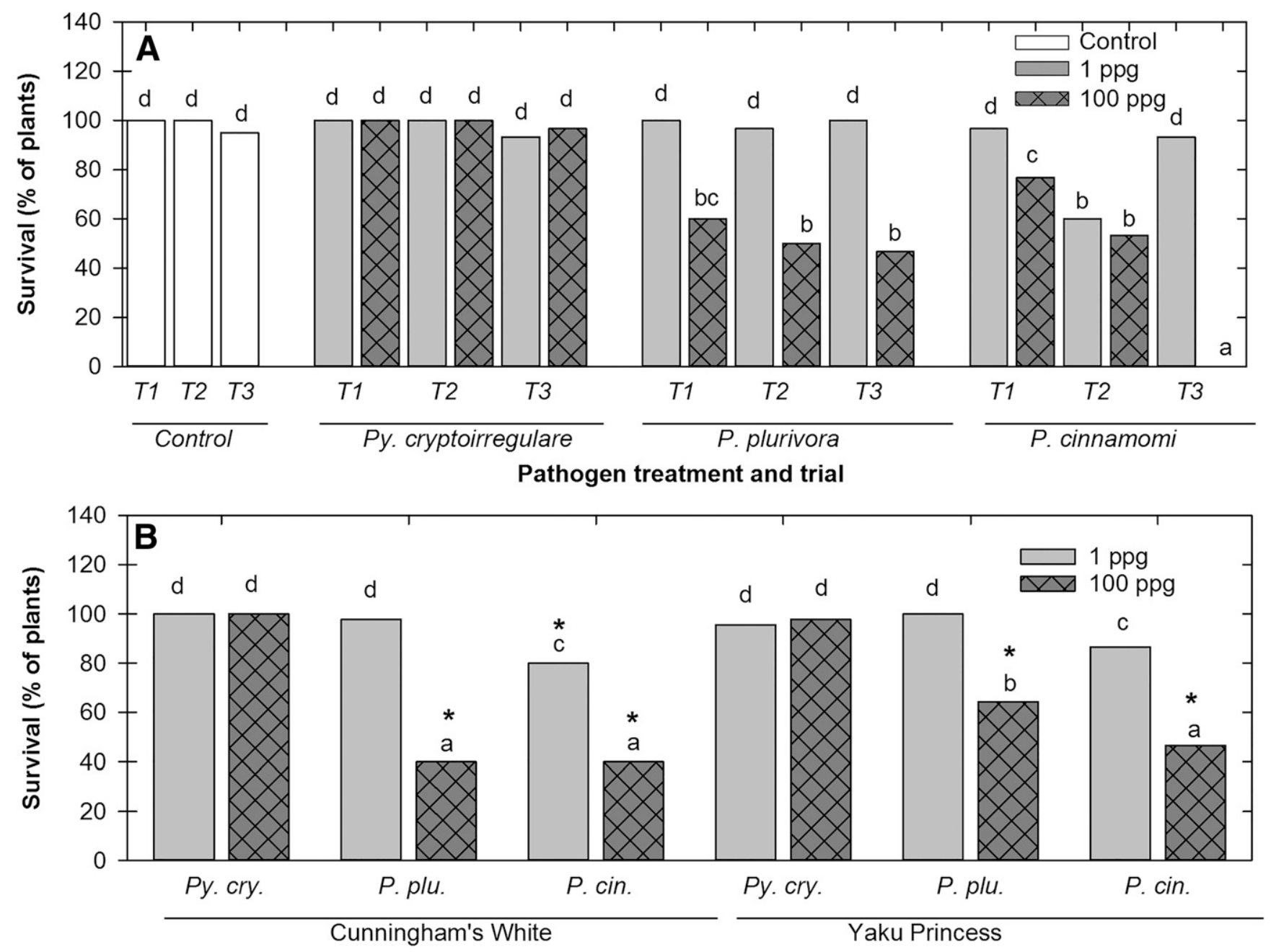

Pathogen treatment and cultivar

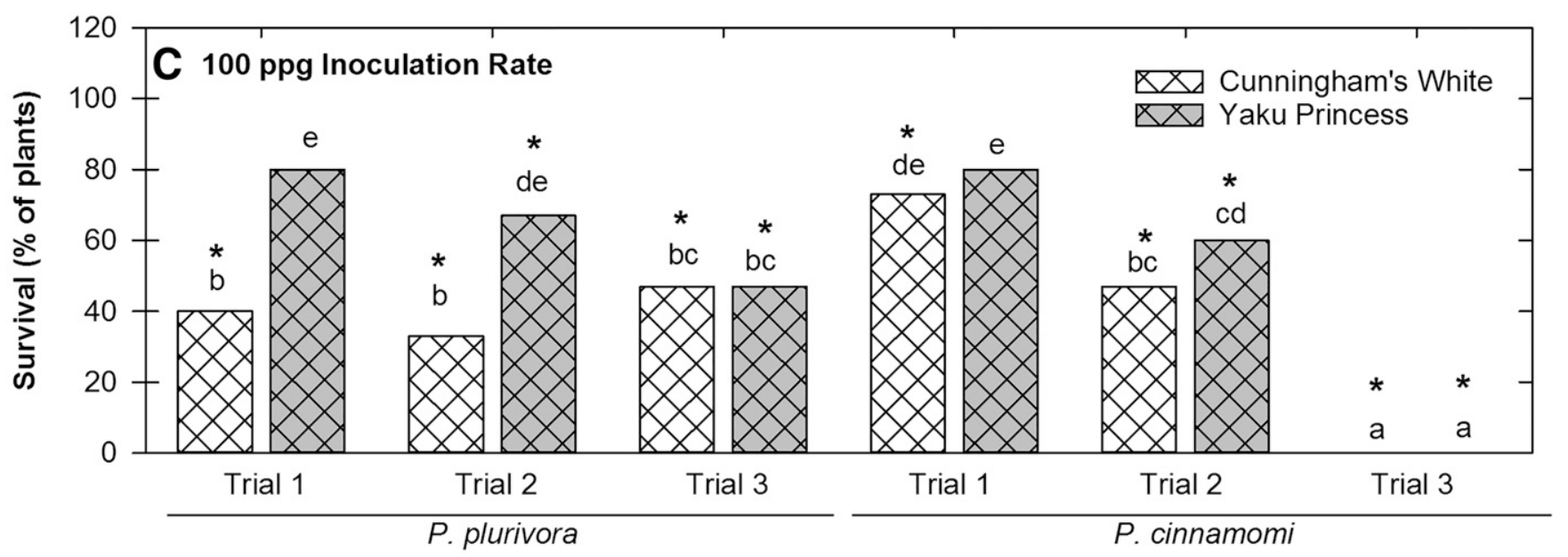

Pathogen treatment and trial

Fig. 4. Percentage of surviving plants of Rhododendron 'Cunningham's White' (CW) and R. 'Yaku Princess' (YP) grown in noninfested media (Control) or media infested with one of three isolates each of Pythium cryptoirregulare (Py. cry.), Phytophthora plurivora (P. plu.), or Phytophthora cinnamomi (P. cin.) at 1 ppg or $100 \mathrm{ppg}$ in three trials. Plants grown for a total of 13 weeks after inoculation. (A) Means across two cultivars and three isolates of each pathogen (Trial $\times$ Pathogen $\times$ Rate; $n=30$ ). Control survival was $100 \%$ in trials 1 and 2 , and $95 \%$ in trial 3. (B) Means across three trials and three isolates of each pathogen (Cultivar $\times$ Pathogen $\times$ Rate; $n=45$ ). (C) Means over three isolates of each pathogen at 100 ppg (Trial $\times$ Cultivar $\times$ Pathogen; $n=15)$. Columns denoted by an asterisk ( $\left.{ }^{*}\right)$ are significantly different than controls $(P<0.05)$. Columns with different lowercase letters denote significant differences among pathogen treatments $(P<0.05)$. 
report that YP, and other rhododendron cultivars with heavy leaf indumentum, appear to be more resistant to Phytophthora root rot than cultivars without this characteristic (Hoitink et al. 2014; J. E. Weiland, personal communication with growers).

Our results support grower observations of cultivar variability in root rot susceptibility and indicate that YP is more resistant to both $P$. cinnamomi and P. plurivora than $\mathrm{CW}$. However, the slower disease progress in YP may also be an indication of tolerance for both pathogens or may mask the cultivar's inherent susceptibility over longer periods of time. Further research is needed to assess additional cultivars with heavy leaf indumentum to find out if they are also more resistant to multiple Phytophthora species. If so, these cultivars may be useful in future breeding programs for Phytophthora root rot resistance. It is also important to note that both P. cinnamomi and P. plurivora were more aggressive on $\mathrm{CW}$ than on $\mathrm{YP}$, suggesting that host resistance might be generally comparable for the two pathogen species: cultivars resistant to $P$. cinnamomi might also be resistant to $P$. plurivora. Our research is therefore first to show that the relative susceptibility or resistance is similar for both pathogens in two rhododendron cultivars. Additional research is needed to confirm whether this is also true on a wider range of rhododendron cultivars and species.

Py. cryptoirregulare was the least aggressive of the three pathogens tested. Although root rot resulting from Py. cryptoirregulare was occasionally moderate or severe, aboveground visual disease symptoms were largely absent and infection rarely spread up into the stem. SPAD values and $g_{s}$ were more sensitive indicators of plant health than visual disease symptoms and showed that $P y$. cryptoirregulare-inoculated plants were periodically more stressed than noninoculated controls. In general, there is little information regarding the effect of Pythium species on rhododendron plant health (Hendrix and Campbell 1966). The only species known to cause severe root rot on rhododendron is $P$ y. prolatum, but this pathogen is rarely encountered in nursery or field plantings (Botha and Crous 1992; Hendrix and Campbell 1969; LéVesque and de Cock 2004) and was not isolated during our survey. Other Pythium species have been isolated from rhododendron, but have not been extensively tested for pathogenicity and are not considered major pathogens except on cuttings and other juvenile plant material (Botha and Crous 1992; Hendrix and Campbell 1966). Our results serve as a first report of Py. cryptoirregulare on rhododendron and indicate that it is a weak pathogen despite its common occurrence on this host in Oregon nurseries. Given that more than one oomycete pathogen can often be isolated from rhododendron nursery plants with root rot (Hendrix and Campbell 1966; Schwingle et al. 2007), it is possible that Py. cryptoirregulare may exacerbate disease if it co-occurs with other Phytophthora or Pythium pathogens. It is unknown how disease complexes involving more than one oomycete pathogen may alter root rot severity in rhododendron nursery production.

$P$. cinnamomi and $P$. plurivora were the most aggressive pathogens tested, and both caused severe root rot, especially at high inoculum levels. Infection frequently spread up from the root system into the lower stem, indicating that both were significantly more aggressive than Py. cryptoirregulare. However, of the two Phytophthora species, $P$. cinnamomi was consistently more aggressive than $P$. plurivora. SPAD values and $g_{s}$ of $P$. cinnamomi-inoculated plants were usually the lowest of any pathogen treatment. In addition, $P$. cinna$m o m i$ killed more plants, caused more severe root rot, and caused the biggest reductions in biomass compared with $P$. plurivora. Hoitink

Table 3. Biomass, root:shoot ratio, and average number of stems in Rhododendron 'Cunningham's White' $(\mathrm{CW})$ and $R$. 'Yaku Princess' (YP) grown in three trials for 13 weeks and not inoculated with any pathogen (Control)

\begin{tabular}{|c|c|c|c|c|c|c|}
\hline \multirow{2}{*}{\multicolumn{2}{|c|}{$\begin{array}{l}\text { Cultivar } \\
\text { and trial }\end{array}$}} & \multicolumn{4}{|c|}{ Biomass $\left(g\right.$ dw) ${ }^{y}$} & \multirow[b]{2}{*}{$\begin{array}{r}\text { Stems } \\
(\text { no. })^{\mathbf{z}}\end{array}$} \\
\hline & & \multirow{2}{*}{$\frac{\text { Roots }}{3.4 \mathrm{bc}}$} & \multirow{2}{*}{$\begin{array}{r}\text { Shoots } \\
5.7 \mathrm{ab}\end{array}$} & \multirow{2}{*}{$\frac{\text { Plant }}{9.1 \mathrm{ab}}$} & \multirow{2}{*}{$\begin{array}{c}\begin{array}{c}\text { R:S } \\
\text { ratio }\end{array} \\
0.62 \mathrm{c}\end{array}$} & \\
\hline $\mathrm{CW}$ & 1 & & & & & $4 \pm 1$ \\
\hline & 2 & $7.4 \mathrm{~d}$ & $10.2 \mathrm{c}$ & $17.6 \mathrm{c}$ & $0.75 \mathrm{~d}$ & $4 \pm 1$ \\
\hline & 3 & $4.3 \mathrm{c}$ & $25.1 \mathrm{~d}$ & $29.3 \mathrm{~d}$ & $0.17 \mathrm{a}$ & $1 \pm 0$ \\
\hline \multirow[t]{3}{*}{ YP } & 1 & $1.4 \mathrm{a}$ & $7.3 \mathrm{ab}$ & $8.7 \mathrm{ab}$ & $0.20 \mathrm{a}$ & $3 \pm 1$ \\
\hline & 2 & $3.0 \mathrm{~b}$ & $9.5 \mathrm{bc}$ & $12.5 \mathrm{~b}$ & $0.31 \mathrm{~b}$ & $3 \pm 1$ \\
\hline & 3 & $0.9 \mathrm{a}$ & $5.4 \mathrm{a}$ & $6.3 \mathrm{a}$ & $0.17 \mathrm{a}$ & $1 \pm 0$ \\
\hline
\end{tabular}

${ }^{\mathrm{y}}$ Mean oven dry weight (dw) of roots, shoots (stems and leaves), whole plant (plant), and ratio of root dry weight to shoot dry weight (R:S ratio) after 13 weeks. Means within a column followed by different lowercase letters are significantly different $(P<0.05$; Trial $1, n=5$; Trials 2 and 3, $n=30)$.

${ }^{\mathrm{z}}$ Mean ( \pm standard deviation) number of primary stems on plants (Stems).

Table 1. Frequency of pathogen reisolation from plants with and without aboveground symptoms of wilting and death

\begin{tabular}{|c|c|c|c|c|}
\hline \multirow[b]{2}{*}{ Aboveground symptom category ${ }^{z}$} & \multicolumn{4}{|c|}{ Pathogen treatment ${ }^{y}$} \\
\hline & Control & Py. cryptoirregulare & P. plurivora & P. cinnamomi \\
\hline Symptoms & $0 \%(0 / 3) \mathrm{A}$ & $100 \%(3 / 3) \mathrm{bAB}$ & $85 \%(44 / 51) b B$ & $97 \%$ (94/97) bB \\
\hline No symptoms & $0 \%(0 / 127) \mathrm{A}$ & $34 \%(60 / 177) \mathrm{aC}$ & $15 \%(20 / 129) a B$ & $30 \%(25 / 83) \mathrm{aC}$ \\
\hline All plants & $0 \%(0 / 130) \mathrm{A}$ & $35 \%(63 / 180) \mathrm{B}$ & $36 \%(64 / 180) \mathrm{B}$ & $66 \%(119 / 180) \mathrm{C}$ \\
\hline
\end{tabular}

y Percentage of plants in each category from which the pathogen was reisolated from either stems or roots followed in parentheses by: (number of plants in each category with pathogen reisolation / total number of plants in each category). Values within a column followed by different lowercase letters and within a row followed by different uppercase letters are significantly different at $P<0.05$.

${ }^{\mathrm{z}}$ Plants with aboveground symptoms of wilting and death (Symptoms), plants without aboveground symptoms (No symptoms), and plants with and without aboveground symptoms combined (All plants). Categories across two inoculation rates (1 and $100 \mathrm{ppg})$, two cultivars ( $R$. 'Cunningham's White' and 'Yaku Princess'), three isolates for each pathogen, and three trials.

Table 2. Frequency of pathogen reisolation from plants in different root rot categories

\begin{tabular}{llccc}
\hline & \multicolumn{4}{c}{ Pathogen treatment $^{\mathbf{y}}$} \\
\cline { 2 - 5 } Root rot category $^{\mathbf{z}}$ & Control & Py. cryptoirregulare & P. plurivora & P. cinnamomi \\
\hline Healthy & $0 \%(0 / 93) \mathrm{A}$ & $25 \%(15 / 61) \mathrm{aB}$ & $24 \%(12 / 51) \mathrm{aB}$ & $9 \%(1 / 11) \mathrm{aB}$ \\
Moderate & $0 \%(0 / 22) \mathrm{A}$ & $16 \%(7 / 45) \mathrm{aA}$ & $10 \%(3 / 29) \mathrm{aA}$ & $5 \%(1 / 19) \mathrm{aA}$ \\
Severe & $0 \%(0 / 5) \mathrm{A}$ & $21 \%(3 / 14) \mathrm{aA}$ & $75 \%(30 / 40) \mathrm{bB}$ & $93 \%(84 / 90) \mathrm{bC}$ \\
All plants & $0 \%(0 / 120) \mathrm{A}$ & $21 \%(25 / 120) \mathrm{B}$ & $37 \%(45 / 120) \mathrm{C}$ & $72 \%(86 / 120) \mathrm{D}$ \\
\hline
\end{tabular}

$\mathrm{y}$ Percentage of plants in each category from which the pathogen was reisolated from either stems or roots followed in parentheses by: (number of plants in each category with pathogen reisolation / total number of plants in each category). Values within a column followed by different lowercase letters and within a row followed by different uppercase letters are significantly different at $P<0.05$.

${ }^{z}$ Plants with no root rot (Healthy, $<10 \%$ rot), moderate root rot (10 to $75 \%$ rot), or severe root rot ( $>75 \%$ rot), and plants with and without root rot combined (All plants). Categories across two inoculation rates ( 1 and 100 ppg), two cultivars ( $R$. 'Cunningham's White' and 'Yaku Princess'), three isolates for each pathogen, and two trials (trials 2 and 3 ). 
and Schmitthenner considered $P$. cinnamomi as the most important pathogen causing root rot in rhododendron (Hoitink and Schmitthenner 1975). However, they also regularly isolated P. citricola from diseased rhododendrons, and several isolates of this pathogen caused just as much root rot as $P$. cinnamomi on $R$. 'Roseum Elegans' (Hoitink and Schmitthenner 1969). It may be that the $P$. citricola isolates that they worked with were actually $P$. plurivora, given that these two closely related species were only recognized as distinct species

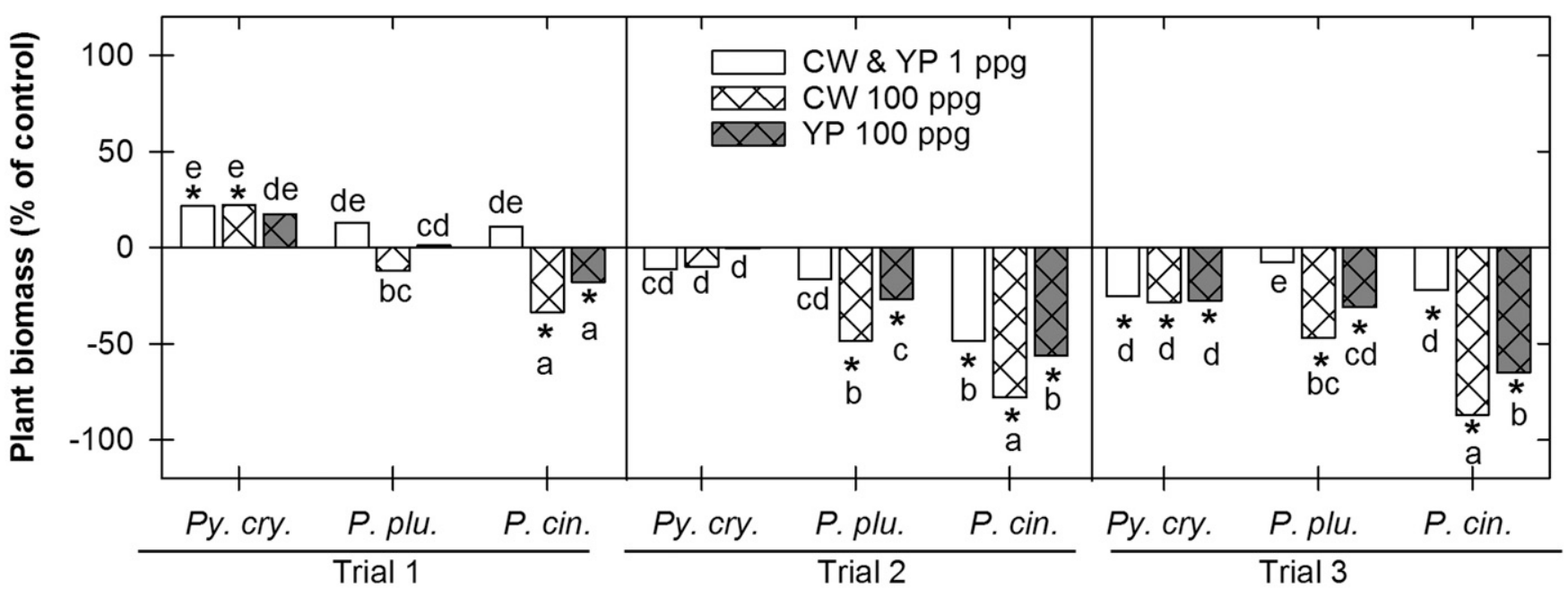

Pathogen treatment and trial

Fig. 5. Difference in biomass compared with controls in Rhododendron 'Cunningham's White' (CW) and $R$. 'Yaku Princess' (YP) grown for 13 weeks after inoculation with one of three isolates each of Pythium cryptoirregulare (Py. cry.), Phytophthora plurivora (P. plu.), or Phytophthora. cinnamomi (P. cin.) at 1 ppg or 100 ppg in three trials. At 1 ppg, average across both cultivars and all isolates within each pathogen presented $(n=30)$. At $100 \mathrm{ppg}$, columns are means across isolates $(n=15)$. Within a trial, columns denoted by different lowercase letters are significantly different at $P<0.05$. Columns denoted by an asterisk $\left(^{*}\right)$ are significantly different from controls at $P<0.05$.

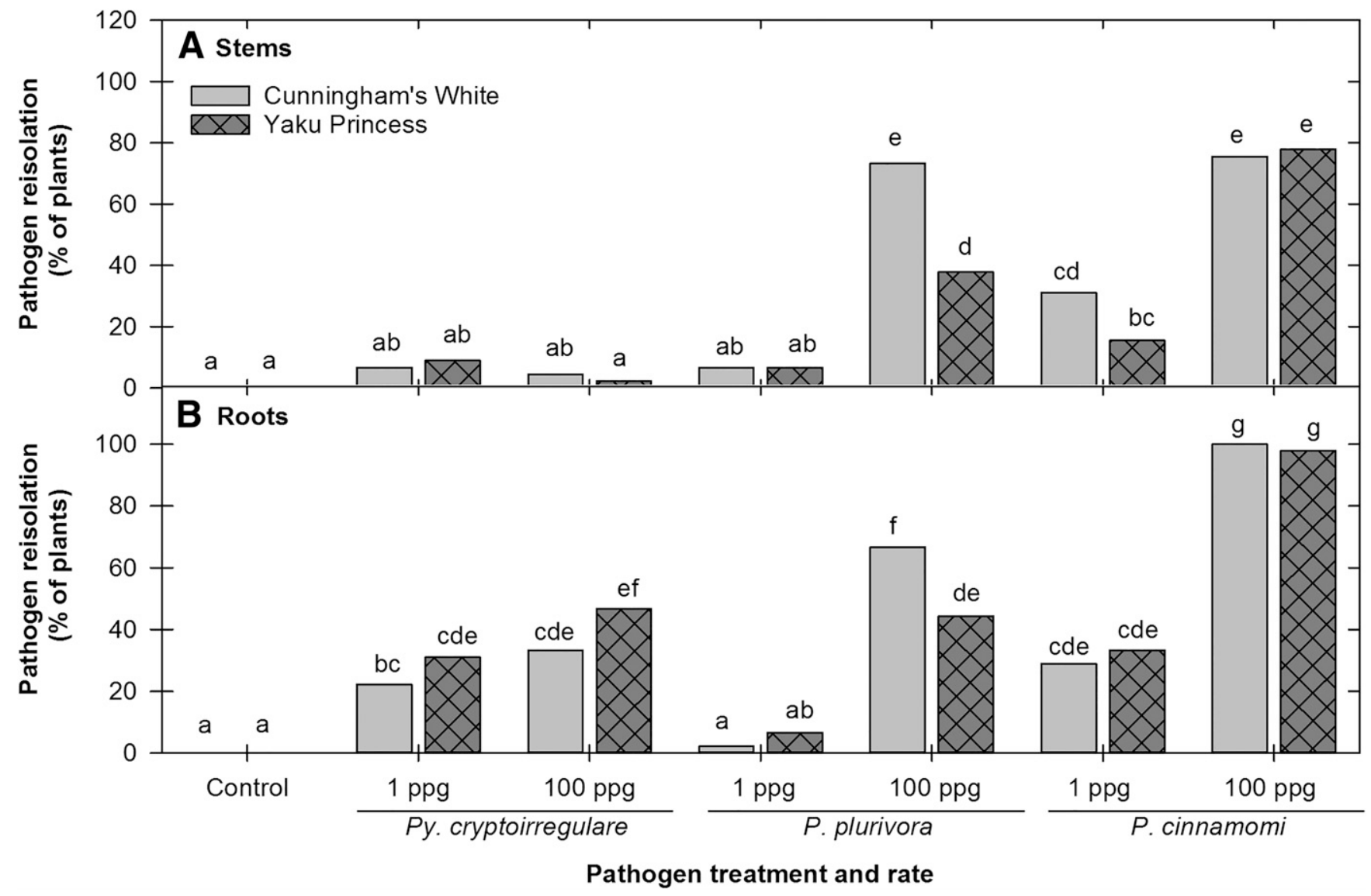

Fig. 6. Percentage of plants from which pathogens were reisolated from stems (A) or roots (B). Reisolation of pathogens from stems and roots in Rhododendron 'Cunningham's White' (CW) and R. 'Yaku Princess' (YP) grown in noninfested media (Control) or media infested with Pythium cryptoirregulare, Phytophthora plurivora, or Phytophthora cinnamomi at $1 \mathrm{ppg}$ or $100 \mathrm{ppg}$ in three trials. Plants were grown for a total of 13 weeks after inoculation. Means over three trials and three isolates of each pathogen (Cultivar $\times$ Pathogen $\times$ Rate; control, $n=65$ and pathogen treatments, $n=45$ ). No pathogens were isolated from stems or roots of control plants. Columns with different lowercase letters denote significant differences across cultivars, pathogens, and inoculation rates $(P<0.05)$. 
in 2009 (Jung and Burgess 2009). However, based on the results of our study, both $P$. cinnamomi and $P$. plurivora should be considered highly virulent pathogens that pose a significant a risk to the rhododendron industry, particularly at high inoculum levels.

Even at low inoculum levels, $P$. cinnamomi, $P$. plurivora, and $P y$. cryptoirregulare were capable of reducing plant health. Aboveground symptoms of chlorosis, wilting, and death were uncommon at $1 \mathrm{ppg}$, but belowground symptoms of root rot were more evident and the final plant biomass was lower than in the controls for trials 2 and 3. So, even in the absence of overt, severe symptoms, relatively low levels of infection could increase the time required for rhododendron nursery stock to reach a marketable size. In addition, there is considerable risk associated with spreading apparently asymptomatic, but otherwise infected plants, throughout the nursery industry and to consumers. It is unknown what the long-term consequences of a low level of infection might be on rhododendron health, particularly after these plants leave the nursery and are planted into the landscape. Disease might continue to slowly develop until more noticeable, severe symptoms appear, or the plants might eventually outgrow the infection and recover. Water stress could also potentially exacerbate disease resulting from low levels of infection and cause symptoms to develop more rapidly. Both drought and excess water have been shown to increase root rot damage in rhododendron (Blaker and MacDonald 1981; Krebs 2013). These types of water stress conditions are common in nurseries during production and in the landscape after the rhododendrons have been transplanted into their final location. Therefore, longer-term studies are needed to determine how low levels of inoculum impact rhododendron health over time.

It was surprising to see a small but significant increase in final plant biomass for several of the pathogen treatments during trial 1 . Our hypothesis was that the soilless media was too dry for optimal infection and disease development, and that the resulting minor root damage stimulated plant growth. Only the most virulent pathogens, $P$. cinnamomi and $P$. plurivora, at the $100 \mathrm{ppg}$ inoculum level were able to reduce biomass, and the latter species was only able to do so on the more susceptible cultivar, CW. This phenomenon where otherwise normally pathogenic species can occasionally stimulate plant growth has been observed in other studies (Dewan and Sivasithamparam 1988; Mazzola et al. 2002). For example, Mazzola et al. (2002) found that apple seedlings of 'Gala' inoculated with specific isolates of Py. sylvaticum and Py. intermedium were sometimes larger than their noninoculated counterparts. Because of our observation of this effect in trial 1 , we increased the irrigation volume in both of the following trials, and the issue was resolved. All subsequent pathogen treatments developed more consistent root disease and had significantly less biomass than the noninoculated controls.

From a diagnostic perspective, the best chances for success in reisolating $P$. cinnamomi or $P$. plurivora were from plants showing severe symptoms of wilting, death, and root rot, whereas Py. cryptoirregulare was more frequently isolated from visually asymptomatic plants or from plants with milder symptoms. The presence of symptoms, however, was not a guarantee for success. For example, P. plurivora was not reisolated from $15 \%$ of the plants with aboveground symptoms, and P. cinnamomi was not reisolated from $7 \%$ of the plants with severe root rot. Species differences in reisolation success were also observed. $P$. cinnamomi was reisolated two to three times more often from symptomatic plants than either P. plurivora or Py. cryptoirregulare, which might suggest that pathogen surveys based on isolation would be biased more toward detecting $P$. cinnamomi than the latter two species. Both Phytophthora species were also reisolated with similar, or slightly lower frequency, from the stems than the roots, but $P y$. cryptoirregulare was always reisolated more frequently from roots. Surveys targeted toward detecting $P$. cinnamomi and $P$. plurivora should focus on sampling the lesions that extend up into the lower stem, rather than the roots, to reduce potential contamination by Py. cryptoirregulare. Together, this knowledge will be useful for understanding how to best sample for the pathogen of interest in future survey work.

In summary, our research shows that both $P$. cinnamomi and $P$. plurivora are aggressive pathogens of rhododendron, and that $P y$. cryptoirregulare is a comparatively weak pathogen. Both inoculum levels resulted in disease, but only the $100 \mathrm{ppg}$ inoculum level consistently caused mortality with the Phytophthora species. The cultivar $\mathrm{CW}$ was more susceptible to $P$. cinnamomi and $P$. plurivora than YP, suggesting that relative host susceptibility was not pathogen specific. Further research is needed to more systematically compare pathogenicity among other soilborne Phytophthora species on a greater number of Rhododendron species and cultivars, and to explore long-term effects of inoculum level on disease progression.

\section{Acknowledgments}

The authors gratefully acknowledge Jesse Mitchell, Suean Ott, Milt Plocher, and Marj Storm for technical assistance. Mention of trade names or commercia products in this publication is solely for the purpose of providing specific information and does not imply recommendation or endorsement by the U.S. Department of Agriculture. USDA is an equal opportunity provider and employer.

\section{Literature Cited}

Benson, D. M. 1990. Landscape survival of fungicide-treated azaleas inoculated with Phytophthora cinnamomi. Plant Dis. 74:635-637.

Benson, D. M., and Cochran, F. D. 1980. Resistance of evergreen hybrid azaleas to root rot caused by Phytophthora cinnamomi. Plant Dis. 64:214-215.

Benson, D. M., Jones, R. K., and Barker, K. R. 1982. Disease loss assessment for azalea, rhododendron, and Japanese holly in North Carolina nurseries. Plant Dis. 66:125-128

Bienapfl, J. C., and Balci, Y. 2014. Movement of Phytophthora spp. in Maryland's nursery trade. Plant Dis. 98:134-144.

Blaker, N. S., and MacDonald, J. D. 1981. Predisposing effects of soil moisture extremes on the susceptibility of rhododendron to Phytophthora root and crown rot. Phytopathology 71:831-834.

Botha, W. J., and Crous, P. W. 1992. A wilt disease of rhododendron caused by Pythium prolatum and Cylindrocladium scoparium. Phytophylactica 24 : 75-78.

Brown, M. B., and Forsythe, A. B. 1974. Robust tests for the equality of variances. J. Am. Stat. Assoc. 69:264-267.

Dewan, M. M., and Sivasithamparam, K. 1988. Pythium spp. in roots of wheat and rye-grass in western Australia and their effect on root rot caused by Gaeumannomyces graminis var. tritici. Soil Biol. Biochem. 20:801-808.

Englander, L., Merlino, J. A., and McGuire, J. J. 1980. Efficacy of two new systemic fungicides and ethazole for control of Phytophthora root rot of Rhododendron, and spread of Phytophthora cinnamomi in propagation benches. Phytopathology 70:1175-1179.

Garzón, C. D., Yanez, J. M., and Moorman, G. W. 2007. Pythium cryptoirregulare, a new species within the $P$. irregulare complex. Mycologia 99:291-301.

Hendrix, F. F., Jr., and Campbell, W. A. 1966. Root rot organisms isolated from ornamental plants in Georgia. Plant Dis. Rep. 50:393-395.

Hendrix, F. F., Jr., and Campbell, W. A. 1969. A new species of Pythium with spiny oogonia. Mycologia 61:387-391.

Hoitink, H. A. J., Benson, D. M., Schmitthenner, A. F., and Jeffers, S. N. 2014 Phytophthora root rot. Pages 5-10 in: Compendium of Rhododendron and Azalea Diseases and Pests, 2nd Ed. R. G. Linderman and D. M. Benson, eds. American Phytopathological Society, St. Paul, MN.

Hoitink, H. A. J., and Schmitthenner, A. F. 1969. Rhododendron wilt caused by Phytophthora citricola. Phytopathology 59:708-709.

Hoitink, H. A. J., and Schmitthenner, A. F. 1974. Relative prevalence and virulence of Phytophthora species involved in rhododendron root rot. Phytopathology 64:1371-1374.

Hoitink, H. A. J., and Schmitthenner, A. F. 1975. Resistance of Rhododendron species and hybrids to Phytophthora root rot. J. Am. Rhododendr. Soc. 29:37-41.

Jung, T., and Burgess, T. I. 2009. Re-evaluation of Phytophthora citricola isolates from multiple woody hosts in Europe and North America reveals a new species, Phytophthora plurivora sp. nov. Persoonia 22:95-110.

Kannwischer, M. E., and Mitchell, D. J. 1978. The influence of a fungicide on the epidemiology of black shank of tobacco. Phytopathology 68:1760-1765.

Knaus, B. J., Fieland, V. J., Graham, K. A., and Grunwald, N. J. 2015. Diversity of foliar Phytophthora species on Rhododendron in Oregon nurseries. Plant Dis. 99:1326-1332.

Krebs, S. 2013. Resistance to Phytophthora root rot varies among rhododendrons subjected to repeated flooding in the field. Acta Hortic. 990:243-253.

Krebs, S. L., and Wilson, M. D. 2002. Resistance to Phytophthora root rot in contemporary rhododendron cultivars. HortScience 37:790-792.

LéVesque, C. A., and de Cock, A. W. A. M. 2004. Molecular phylogeny and taxonomy of the genus Pythium. Mycol. Res. 108:1363-1383.

Linderman, R. G., and Zeitoun, F. 1977. Phytophthora cinnamomi causing root rot and wilt of nursery-grown native western azalea and salal. Plant Dis. Rep. 61 $1045-1048$

Madden, L. V., Hughes, G., and van den Bosch, F. 2007. The Study of Plant Disease Epidemics. American Phytopathological Society, St. Paul, MN.

Madden, L. V., Turechek, W. W., and Nita, M. 2002. Evaluation of generalized linear mixed models for analyzing disease incidence data obtained in designed experiments. Plant Dis. 86:316-325. 
Manning, W. J., and Crossan, D. F. 1966. Evidence for variation in degree of pathogenicity of isolates of Phytophthora cinnamomi to broadleaf and coniferous evergreens. Plant Dis. Rep. 50:647-649.

Mantel, N. 1974. Comment and suggestion on the Yates continuity correction. J. Am. Stat. Assoc. 69:378-380.

Martin, F. N., and Coffey, M. D. 2012. Mitochondrial haplotype analysis for differentiation of isolates of Phytophthora cinnamomi. Phytopathology 102: 229-239.

Mazzola, M., Andrews, P. K., Reganold, J. P., and LéVesque, C. A. 2002. Frequency, virulence, and metalaxyl sensitivity of Pythium spp. isolated from apple roots under conventional and organic production systems. Plant Dis. 86:669-675.

McGuire, J. J., and Jackson, N. 1973. Influence of environment on incidence of Phytophthora root rot in four varieties of rhododendrons in containers. Am. Rhod. Soc. 27:120-123.

Mrázková, M., Černý, K., Tomšovský, M., and Strnadová, V. 2011. Phytophthora plurivora T. Jung \& T. I. Burgess and other Phytophthora species causing important diseases of ericaceous plants in the Czech Republic. Plant Prot. Sci. 47:13-19.

Orlikowski, L., and Szkuta, G. 2008. The menace of hardy ornamental nursery stocks by Phytophthora spp. in the last 15 years. Sylwan 152:44-50.

Parke, J. L., Knaus, B. J., Fieland, V. J., Lewis, C., and Grunwald, N. J. 2014. Phytophthora community structure analyses in Oregon nurseries inform systems approaches to disease management. Phytopathology 104:1052-1062.

Prospero, S., Vercauteren, A., Heungens, K., Belbahri, L., and Rigling, D. 2013. Phytophthora diversity and the population structure of Phytophthora ramorum in Swiss ornamental nurseries. Plant Pathol. 62:1063-1071.

Rytkönen, A., Lilja, A., Vercauteren, A., Sirkiä, S., Parikka, P., Soukainen, M., and Hantula, J. 2012. Identity and potential pathogenicity of Phytophthora species found on symptomatic Rhododendron plants in a Finnish nursery. Can. J. Plant Pathol. 34:255-267.
Scagel, C. F., Bi, G. H., Fuchigami, L. H., and Regan, R. P. 2011. Effects of irrigation frequency and nitrogen fertilizer rate on water stress, nitrogen uptake, and plant growth of container-grown rhododendron. HortScience 46 1598-1603.

Scanu, B., Hunter, G. C., Linaldeddu, B. T., Franceschini, A., Maddau, L., Jung, T., and Denman, S. 2014. A taxonomic re-evaluation reveals that Phytophthora cinnamomi and $P$. cinnamomi var. parvispora are separate species. For. Pathol. 44:1-20.

Schoebel, C. N., Stewart, J., Gruenwald, N. J., Rigling, D., and Prospero, S. 2014. Population history and pathways of spread of the plant pathogen Phytophthora plurivora. PLoS One 9:e85368.

Schwingle, B. W., Smith, J. A., and Blanchette, R. A. 2007. Phytophthora species associated with diseased woody ornamentals in Minnesota nurseries. Plant Dis. 91:97-102.

Shapiro, S. S., Wilk, M. B., and Chen, H. J. 1968. A comparative study of various tests of normality. J. Am. Stat. Assoc. 63:1343-1372.

Simko, I., and Piepho, H. 2012. The area under the disease progress stairs Calculation, advantage, and application. Phytopathology 102:381-389.

Sokal, R. R., and Rohlf, F. J. 2012. Biometry, 4th Ed. W. H. Freeman and Company, New York, NY.

USDA National Agricultural Statistics Service. 2015. 2014 Census of Horticultural Specialties. Online publication. https://www.agcensus.usda.gov/Publications/ 2012/Online Resources/Census of Horticulture Specialties/.

Warfield, C. Y., Hwang, J., and Benson, D. M. 2008. Phytophthora blight and dieback in North Carolina nurseries during a 2003 survey. Plant Dis. 92 474-481.

Weiland, J. E., Santamaria, L., and Grunwald, N. J. 2014. Sensitivity of Pythium irregulare, $P$. sylvaticum, and $P$. ultimum from forest nurseries to mefenoxam and fosetyl-Al, and control of Pythium damping-off. Plant Dis. 98:937-942.

White, R. P. 1930. Two Phytophthora diseases of Rhododendron. (Abstr.) Phytopathology 20:131.

White, R. P. 1937. Rhododendron wilt and root rot. N.J. Agric. Exp. Stn. Bull. 615. 